\title{
On The Design of Web-Based Information and Booking System for Futsal Field Rental Business
}

\author{
Moechammad Sarosa \\ Department of Electrical Engineering \\ State Polytechnic of Malang \\ Malang, Indonesia
}

\author{
Wahyu Indah Permana \\ Department of Electrical Engineering \\ State Polytechnic of Malang \\ Malang, Indonesia
}

\author{
Verda Nurohmansah \\ Department of Electrical Engineering \\ State Polytechnic of Malang \\ Malang, Indonesia
}

\author{
Yoyok Heru Prasetyo Isnomo \\ Department of Electrical Engineering \\ State Polytechnic of Malang \\ Malang, Indonesia
}

\begin{abstract}
Limited free space for doing sports makes a lot of leased sports facilities, including futsal field. Nowadays, if someone wants to rent futsal field, a customer should make a reservation manually by going to the location or call the manager. This research tries to offer a solution in the form of web design for the owners of futsal field rental business. The designed website will provide registration services for field owners to promote their field to potential customers. The web will display information of several futsal fields that have registered in the form of location, schedule with its booking list and order procedure so that prospective customers could choose and place their order according to desired field and time. The web also features field location's map using google maps so that prospective buyer could know the exact location of each futsal field and the possible routes to the location. This information system has been tested on several computers and mobile phones connected to the internet. Testing result shows that this website has a responsive appearance. The site will adjust to the screen size when accessed devices with various specifications. The time delay in displaying a webpage depends on the quality of the network and the Android version of the device used.
\end{abstract}

Keywords: futsal field, information system, booking, service providers, rental business, reservation

\section{INTRODUCTION}

Limited available space to play sports makes futsal becomes a very popular sport since it does not need many spaces. This has led to a new business area such as futsal field rental which began to gain popularity. However, many of the field rental schedule management still be done manually and the booking still was done via phone or come directly to the location. With the rapid development of information technology, it is logical if an information system is developed to solve various problems in the futsal field rental [1] [2].

This research tries to develop a web application that provides services and booking information systems for managing the futsal field rental business. With this application, the futsal field entrepreneur (owner) can promote his futsal field, manage the booking and playing schedule [3].

The app also has supportive features, such as field-based searches, location map, rating the most popular field, and provide information and validation of each respective futsal, in which each owner has different rules. Another service provided by the application is information about the futsal field which is empty or has not been rented. However, the financial transactions made directly to related parties [4]

This application can help the field manager keep records such as field renter report and the customers can find information about the availability of the futsal field. Customers can also use
Google Maps application which is included in the apps to show the location of registered places in the apps [5].

\section{SYSTEM PLANNING}

The web application is made using multiple software, such as Macromedia, Dreamweaver, Xampp, MySQL and also Google Maps API to show the locations of the futsal field [6] [7] [8].

This website divided into several parts, first is a user interface design that directly interacts with a user, including several commands to call the other part. Logic part is the other part of this website, in which it contains the core program and commands to access a database. While the database part that has some supportive add on an additional feature is called model part the three parts will be combined to form a webpage that satisfies user requirements [9].

This application is built according to System Development Life Cycle (SDLC) phases, in which an information system could support required application in the form of system design, building, and user presentation. SDLC has four main phases, namely: planning, analysis, design, and implementation [10]

\subsection{System Description}

This website is designed as a service media for renting futsal field aiming at providing web-based field rental service, 
including information media, rental facility, and rental schedule. The outline diagram of the application can be described as follows:

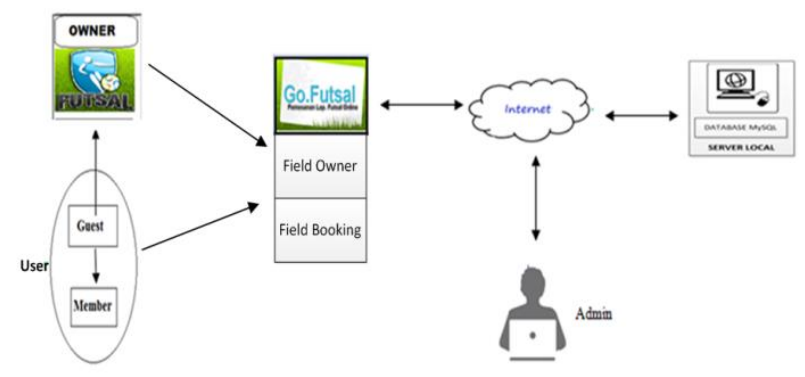

Figure 1. System block diagram

The system provides 4 types of access namely:

- Admin, in charge of managing the registration validation and viewing reports on the booking

- An owner, in charge of managing the booking schedule and the rental tariff.

- Guest will be able to register as a member, browse the information related to the futsal field registered on this website.

- Member will be able to book a field based on a futsal field search, date, price and time, and register his futsal field rental to this website.

Figure 2 shows the use case diagram which has 4 actors: Guest, Member, Owner, and Admin. Member, Owner, and Admin must login first to get into the system.

On the other hand, Guest can access the system without login. Guest can view the information about the futsal place, search field, schedule information, and see the location map. Guest can also register to become a member of the website.

Member can view the information about the futsal place, search field, schedule information, and see the location map. Member must login into the system to access the booking menu, see the history of booking and edit user accounts. The owner must login to access the menu which is changing the account data, add and change places data, add and change field data, add and change the data tariff, view the reports of the reservation, and validate the booking field.

Admin can change data account, validate the owner reservations, view report, view owner booking reports, and view member reports.

\subsection{Use Case Diagram}

Use Case diagram with 4 entities that cover admin, owner, user, and guest, shown in Figure 2.

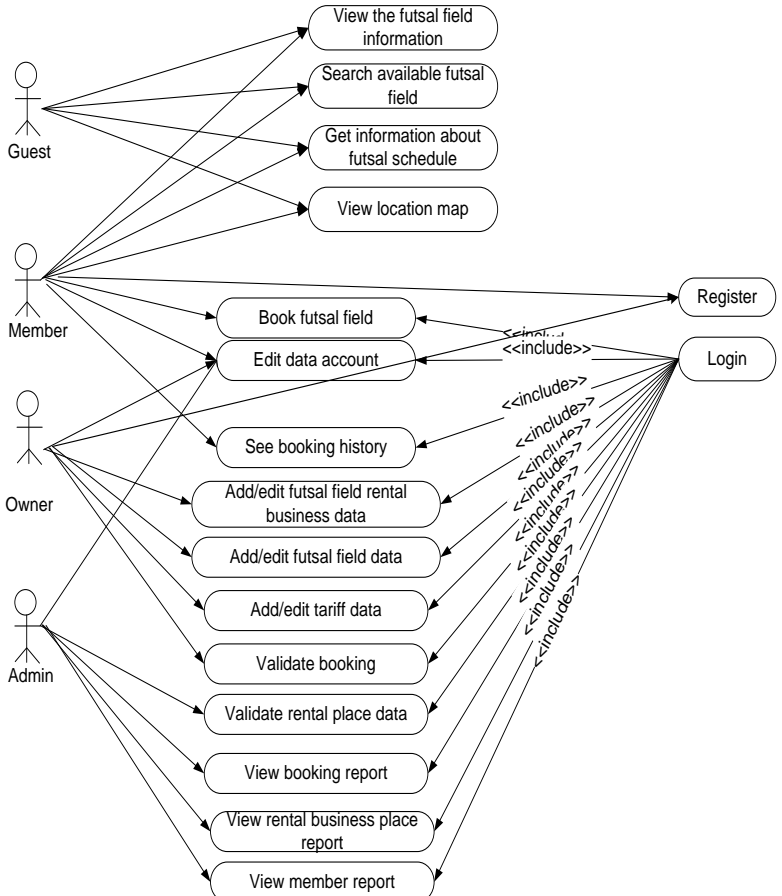

Figure 2. Usecase diagram

\subsection{System Flowchart}

System flowchart built for user, owner, and admin entity shown in Figure 3, 4, and 5, respectively.

\subsubsection{User}

The futsal field booking application can be operated by the user namely a guest and members. When the application is running, the flow charts when users access the system shown in Figure 3.

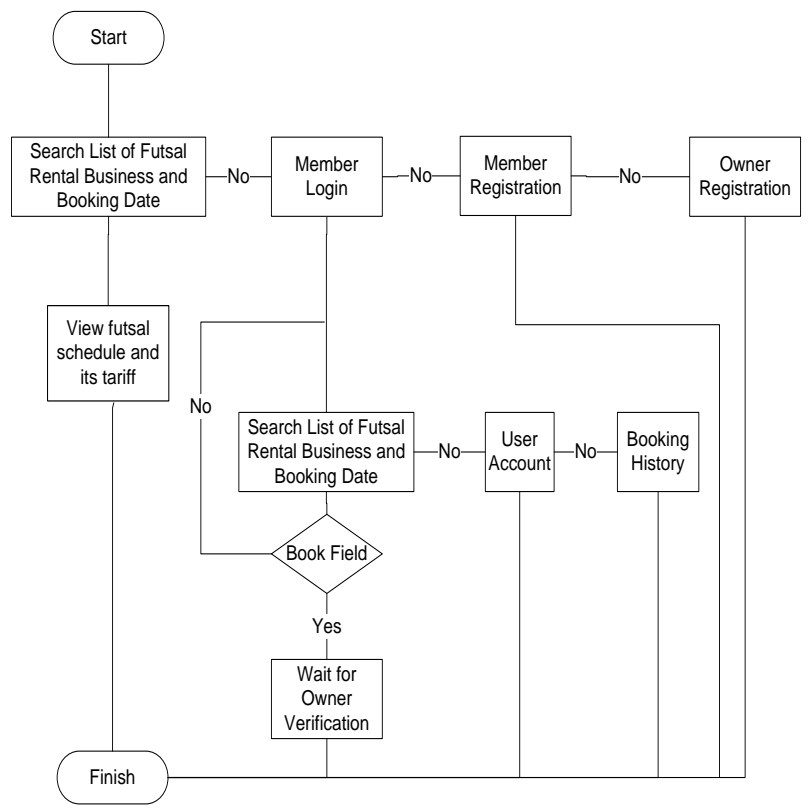

Figure 3. Flowchart of "User" 
The user stated in Figure 3 can be the guests and members. Guest can only view available futsal fields, and when a guest is interested, he can register as a member and can access the member menu such as booking the field, edit a user account, and view a history of booking. Guest can also register as an owner if he has a futsal field rental.

\subsubsection{Owner}

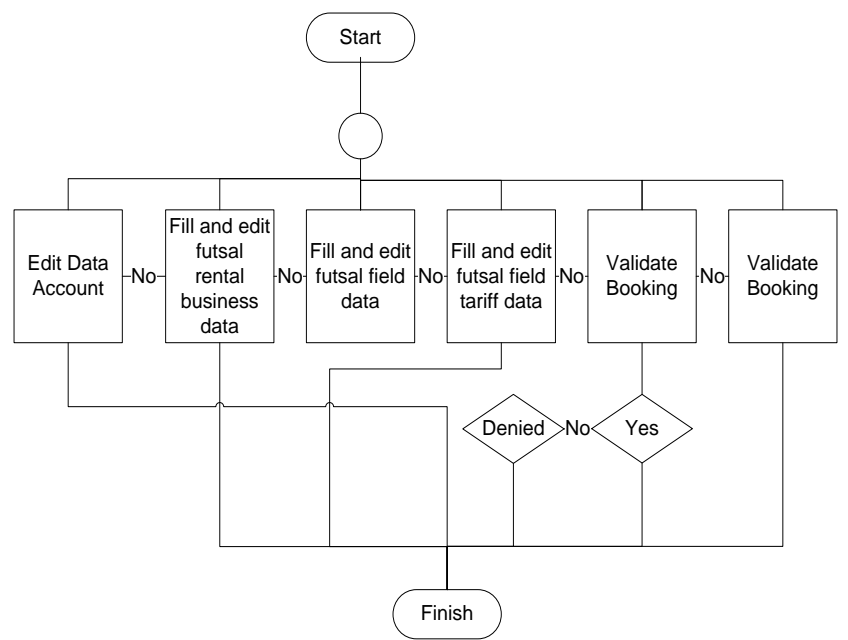

Figure 4. Flowchart of "Owner"

The owner can fill and update data account, fill the data and photos of the futsal field rental and the field itself, also fill and edit the futsal rental tariff, bevalidating field reservations booked by the user as valid or invalid, and also view the booking report.

\subsubsection{Admin}

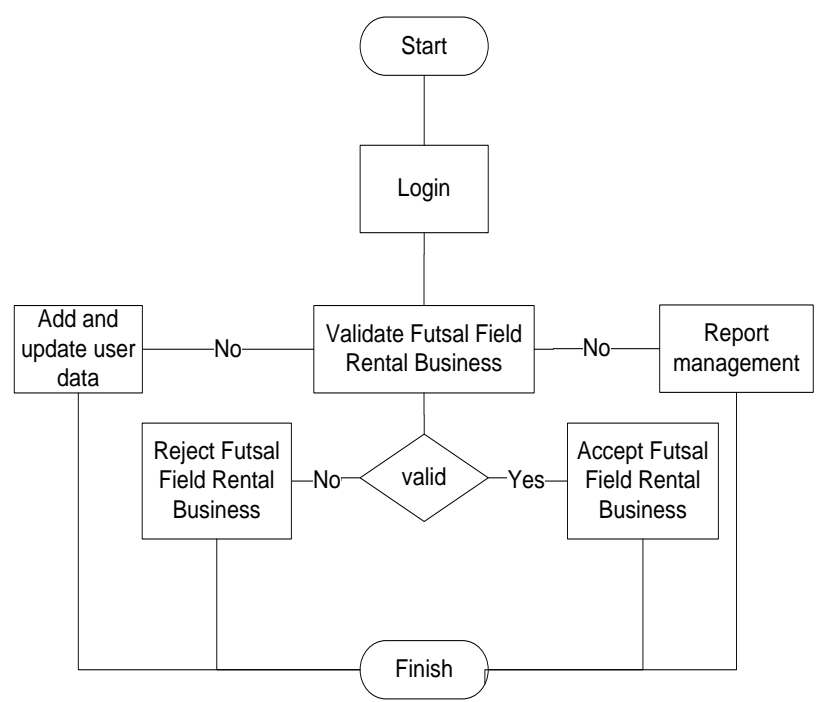

Figure 5. Flowchart of "Admin"

Admin should login with a particular username and password. An admin can add admin data and check the validation of the booking. If there is a new owner registered and the owner data is correct then admin will give "valid" status, so the futsal field belonging to the new owner can be displayed in a web. If the owner data is incorrect or does not fit the requirement, then admin will reject owner. Admin of report management division can view the booking report, rental places and members report.

\section{TESTING OF APPLICATION MENU}

Testing was done to observe the function of each menu, explained below:

\subsection{Testing Booking Futsal Field Menu \\ Pencarian}

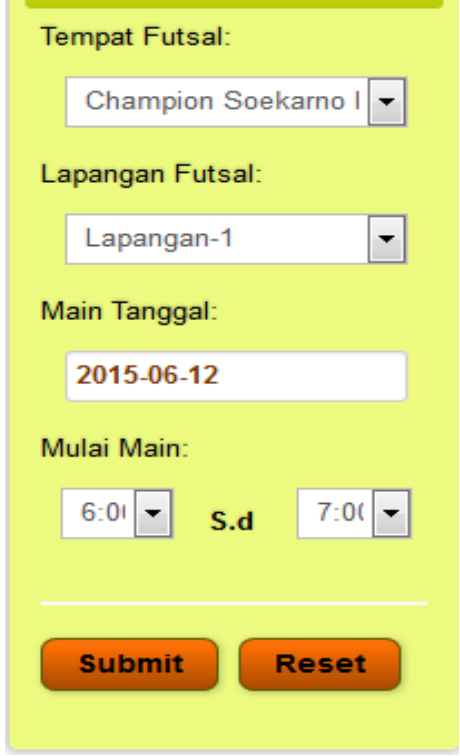

Figure 5. Search futsal field rental business

This page showedall the registered futsal field rental place which is available to be booked. If a user wants to book the futsal field, a user should select the futsal field rental place, desired date and time a user starts to play. For example, book the Champion SoekarnoHatta futsal field at June $12^{\text {th }}, 2015$, 06:00-07:00 a.m.

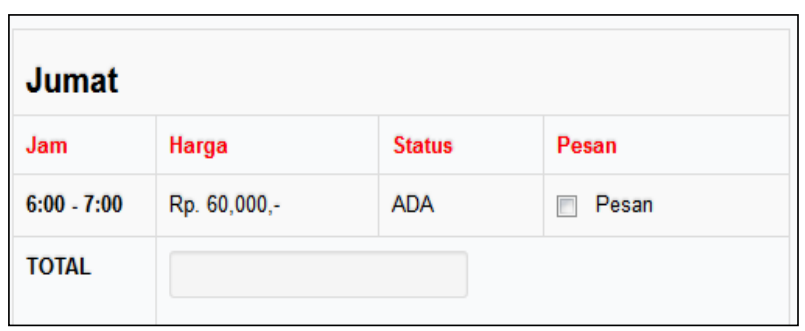

Figure 6. Booking futsal field

On the futsal field schedule page, if the selected field is available then a user could choose "book" and the total price user should pay appears automatically according to the booking tariff.

\subsection{Testing Registration of Futsal Field Rental Business}

For an owner who wants to register their futsal field rental business, the owner should first enter the registration page of a new owner and fill in the data to be able to log into the web application. After login into the web, an owner can fill all field 
data futsal namely user account data, place, fields and field tariff data.

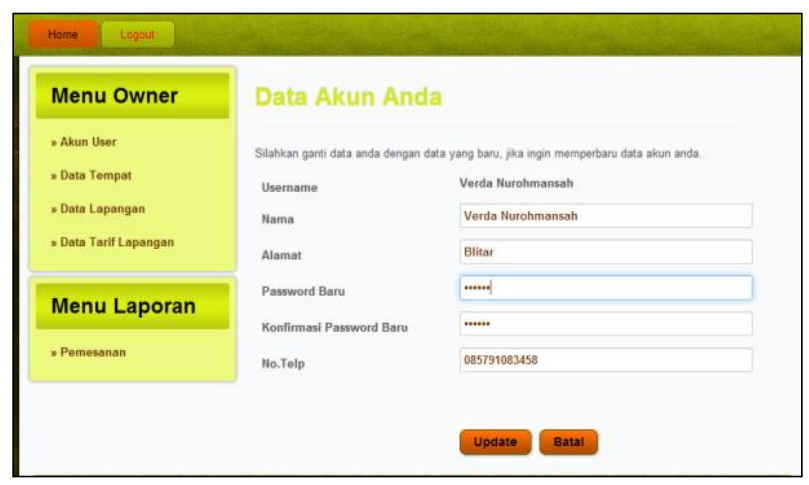

Figure 7. Menu owner's data account

If an owner wants to change the new data then he must change the desired data and press the update button to save the data, so that the data can be updated.

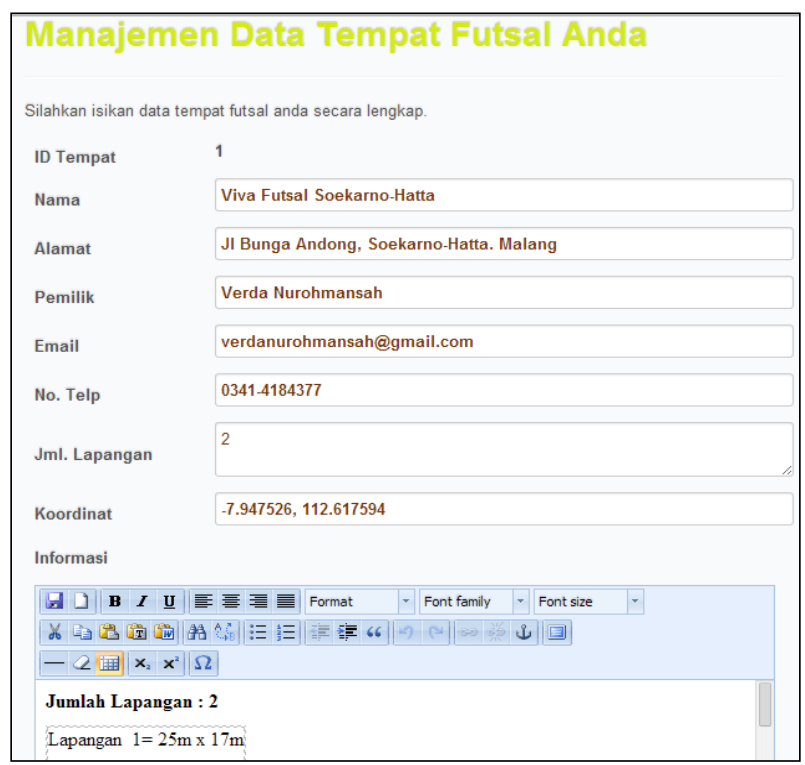

Figure 8. Rental business' data menu

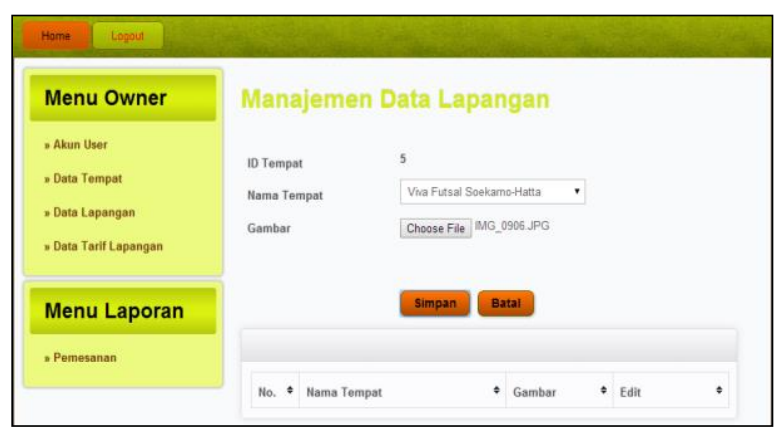

Figure 9. Futsal field' data menu

An owner who has successfully fill in the data about his futsal field could continue to the field data menu in which he will upload the futsal filed' photos.

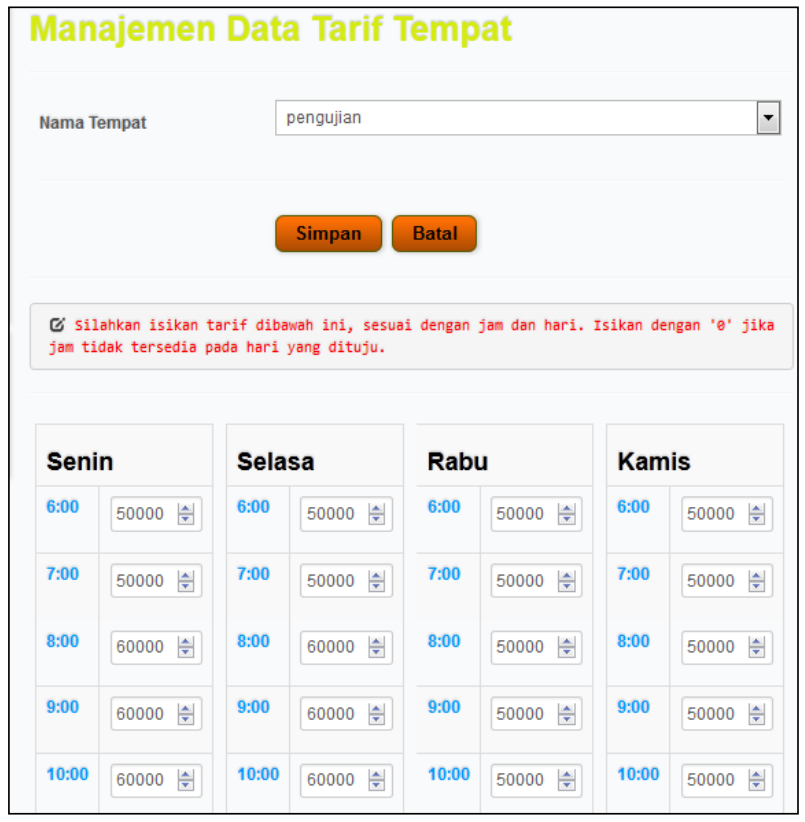

Figure 10. Futsal field tariff menu

\subsection{Web Design Responsivity Testing}

Responsivity testing is aimed to obtain the information system display size suitability on a variety of different devices such as computers and smartphones. The information system can adjust the display size on the device screen used which influence the displayed information.

\subsection{The Test result for screen size $>1280$ pixels}

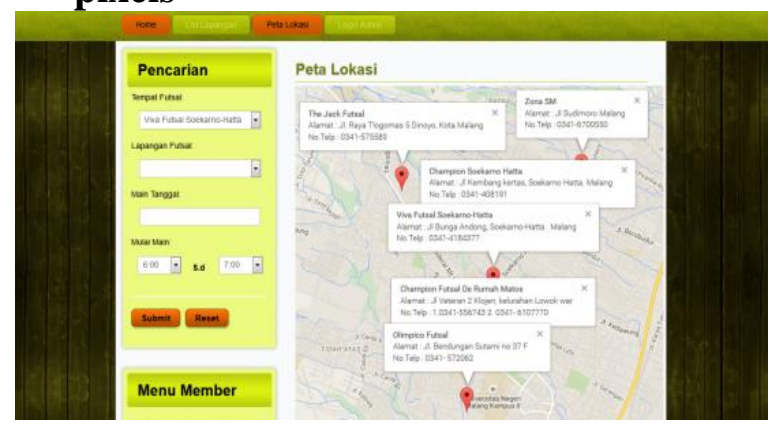

Figure 11. Screen size display in PC

Figure 11 shows the display in which the screen size is larger than 1280 pixels or computer screen. At this size, the map could show all registered futsal place in Malang, such as The Jack Futsal, Zone SM, Champion Soekarno-Hatta, Viva Futsal Champion de house Malang Town Square and Futsal Olimpico.

\subsection{The Test result for screen size $<768$ pixels}

Figure 12 shows the display for screen size $<768$ pixels or screen for tablets. At this size, a map can only display 4 out of $6(67 \%)$ registered futsal place in the city of Malang, which are The Jack Futsal, Zone SM, Champion SoekarnoHatta and Viva Futsal. 


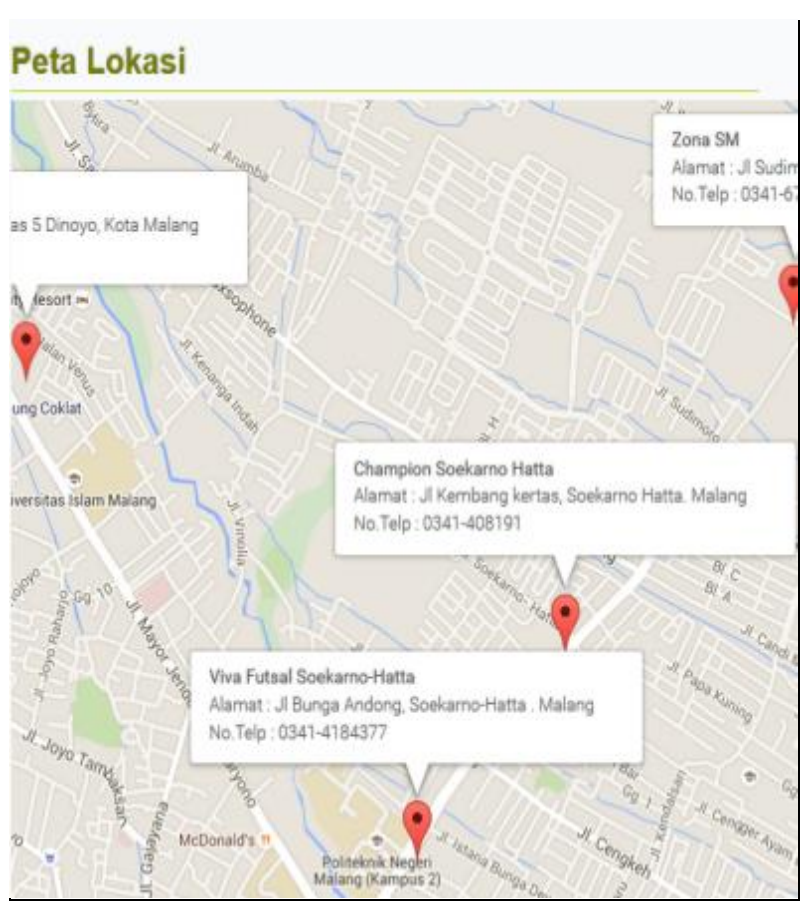

Figure 12. Screen size display in tablet

\subsection{The Test result to screen size $<480$ pixels}

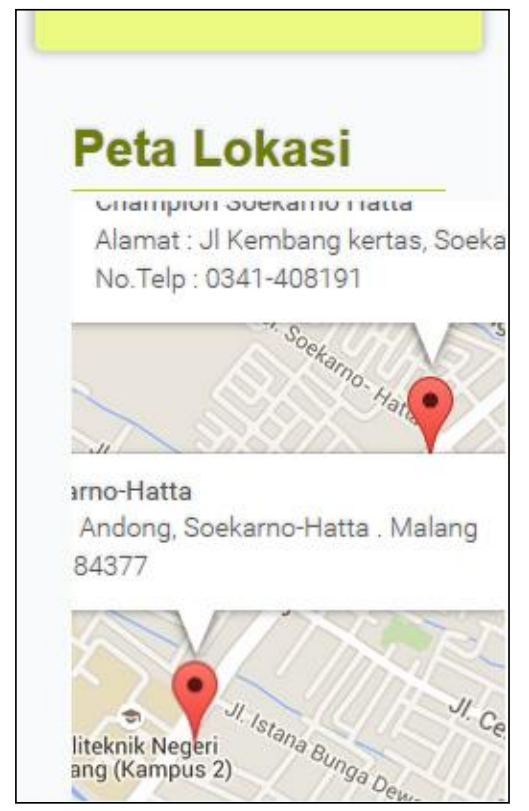

Figure 13. Screen size display in a smartphone

Figure 13 shows the display for screen size $<480$ pixels or screens for smartphones. On this size, a map can only display 2 area out of $6(33 \%)$ registered futsal rental place in the city of Malang which are Viva Champion Futsal Futsal and SoekarnoHatta.

\subsection{Testing on a variety of device}

Testing was conducted on some smartphones at the same time to determine the feasibility of the new application. Testing was conducted using 5 different smartphone versions and brands, types of Internet data packets are the same at the same time and in the same place.

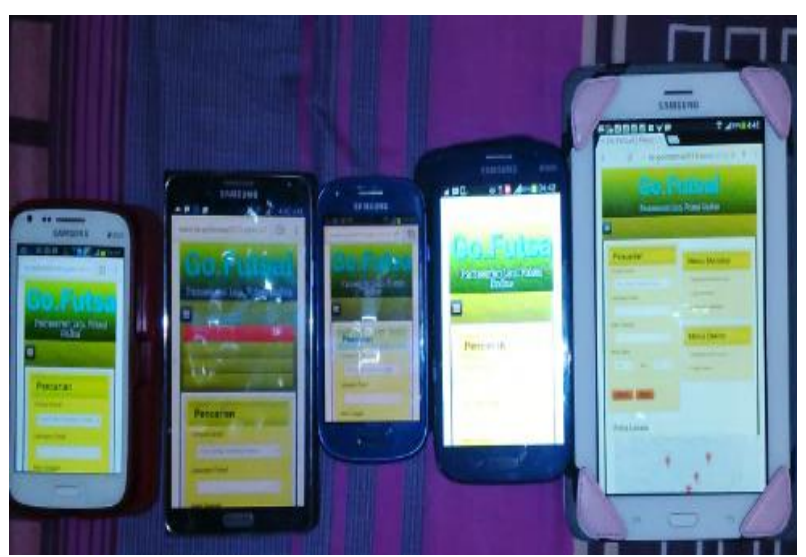

Figure 14. Testing on a variety of device

Table 1. Delay In Android Version 4.2.3

\begin{tabular}{|c|c|c|c|c|c|c|c|c|}
\hline & $\begin{array}{l}\text { Hardware } \\
\text { Specification } \\
\text { (RAM and } \\
\text { Processor) }\end{array}$ & $\begin{array}{l}\text { Android } \\
\text { Version }\end{array}$ & $\begin{array}{l}\text { Downlink } \\
\text { Rate }\end{array}$ & & $\begin{array}{l}\text { ay (s) } \\
\text { Irsday } \\
06 / 2 \\
\text { day } \\
4 \text { p.m }\end{array}$ & 15)- & 015) & $\begin{array}{l}\text { Average } \\
\text { Delay } \\
\text { (s) }\end{array}$ \\
\hline & & & & Thu & Fri & Sat & Sun & \\
\hline 1 & Smartphone A & 4.2 .3 & $\begin{array}{l}\text { Up to } 7.2 \\
\text { Mbps }\end{array}$ & 3 & 3 & 4 & 3 & 3.25 \\
\hline 2 & Smartphone E & 4.2 .3 & $\begin{array}{l}\text { Up to } 7.2 \\
\text { Mbps }\end{array}$ & 3 & 3 & 5 & 4 & 3.75 \\
\hline & al Average De & & & & & & & 3.5 \\
\hline
\end{tabular}

From the above results, network traffic and smartphone brands during rush hour affect the application delay. In HSDPA+ network which its downlink rate is up to $7.2 \mathrm{Mbps}$, there is a delay on the Smartphone A of 3.25 seconds and in Smartphone E with a delay of 3.75 seconds, so that the average delay is 3.5 seconds.

From Table 2, network traffic and smartphone brands during rush hour also affect the application delay in older android version. In HSDPA network which its downlink rate is up to 7.2 Mbps, there is a delay on the Smartphone C of 5.25 seconds and in Smartphone B with a delay of 7 seconds, so that the average delay is 6.25 seconds.

Table 2. Delay In Android Version 4.2.2

\begin{tabular}{|c|c|c|c|c|c|c|c|c|}
\hline \multirow[t]{2}{*}{ No } & \multirow[t]{2}{*}{$\begin{array}{l}\text { Hardware } \\
\text { Specification } \\
\text { (RAM and } \\
\text { Processor) }\end{array}$} & \multirow[t]{2}{*}{$\begin{array}{c}\text { Android } \\
\text { Version }\end{array}$} & \multirow[t]{2}{*}{$\begin{array}{c}\text { Downlink } \\
\text { Rate }\end{array}$} & \multicolumn{4}{|c|}{$\begin{array}{c}\text { Delay (s) } \\
\text { Thursday }(25 / 06 / 2015) \\
\text {-Sunday }(28 / 06 / 2015) \\
3.44 \text { p.m }\end{array}$} & \multirow[t]{2}{*}{$\begin{array}{c}\text { Average } \\
\text { Delay } \\
\text { (s) }\end{array}$} \\
\hline & & & & Thu & Fri & Sat & Sun & \\
\hline 1 & $\begin{array}{c}\text { Smartphone } \\
\text { B }\end{array}$ & 4.2 .2 & $\begin{array}{c}\text { Up to } 7.2 \\
\text { Mbps }\end{array}$ & 6 & 6 & 10 & 6 & 7 \\
\hline 2 & $\begin{array}{l}\text { Smartphone } \\
\text { C }\end{array}$ & 4.2 .2 & $\begin{array}{c}\text { Up to } 7.2 \\
\text { Mbps }\end{array}$ & 5 & 6 & 5 & 5 & 5.25 \\
\hline 3 & $\begin{array}{c}\text { Smartphone } \\
\text { D }\end{array}$ & 4.2 .2 & $\begin{array}{c}\text { Up to } 7.2 \\
\text { Mbps }\end{array}$ & 6 & 5 & 9 & 6 & 6.5 \\
\hline \multicolumn{8}{|c|}{ Total Average Delay (s) } & 6.25 \\
\hline
\end{tabular}




\section{CONCLUSION}

The applications could be used properly in accordance with the design and there is no mistake in the process of displaying information. Based on test results performed on the screen size> 1280 pixels, $<768$ and $<480$ pixels, the system had a responsive view, means that the displayed information can adjust to the screen size when accessed on a variety of devices such as computers and smartphones. The percentage of displayed map image by the device on screen size $>1280$ pixels is $100 \%,<768$ pixel is $67 \%$ and screen size $<480$ pixel is $33 \%$. From the smartphone-based test obtained in the same time with the same brand and android version of 4.2.3, the average delay time is 3.5 seconds, while in android version 4.2.2, then average delay time reaches 6.25 seconds. It can be concluded that the slow and fast access time depends on the android version of the smartphone.

In the future, the system can be developed with the facility of payment via e-banking. and can be equipped with socialmedia to remind the user who booked the field.

\section{BIBLIOGRAPHY}

[1] Zakaria R.Z., "SistemInformasiPenyewaanLapangan Futsal Berbasis Web Dan SMS Gateway (StudiKasus Goal Arena Futsal).," JurnalUniversitas Pembangunan Nasional Veteran JawaTimur., 2013.

[2] Kristiandi H., "Pembangunan Aplikasi Mobile PencarianPersewaanLapangan Futsal di Yogyakarta BerbasisLokasi," UniversitasAtma Jaya, Yogyakarta, Doctoral Dissertation 2014.
[3] Ruhmawan, A.R. and Nurwidyantoro, A., "SistemInformasiPemesananLapangan Futsal Berbasis Web," UniversitasGadjahMada, Yogyakarta, Doctoral Dissertation 2015.

[4] Maimunah , Hariyansyah , and Jihadi, G, "RancangBangunSistemAplikasiPenyewaanLapangan Futsal Berbasis Web," in Seminar NasionalTeknologiInformasidan Multimedia, STMIK Amikom, Yogyakarta, 2017, pp. 4.7-7 - 4.7-12.

[5] Jannah, E.N. and Hidayah, A., "SistemTerintegrasiBerbasis Web untukPencariandanPemesananKelompokSeniPertunjuk an.,"

JurnalNasionalTeknikElektrodanTeknologiInformasi (JNTETI), vol. 5(4)., 2016.

[6] Hu, S. and Dai, T., "Online Map Application Development Using Google Maps API, SQL Database, and ASP.NET.," International Journal of Information and Communication Technology Research, vol. 3(3)., 2013.

[7] Anhar ST., PanduanMenguasai PHP dan MySQL secaraotodidak. Jakarta, Indonesia: Mediakita, 2010.

[8] Nugroho T., Practice Guide PHP on Windows. Jakarta, Indonesia: PT. Elex Media Komputindo, 2009.

[9] Zamahsari, Sarosa M., and Nurwasito H., "Concept of Designing an Optimized Pull Model View," International Journal of Computer Applications (IJCA), vol. 57(20), pp. 9-13, 2012.

[10] Sommerville I, Software Engineering $9^{\text {th }}$ Edition.: China Machine Press, 2011. 